\title{
Comparison of hydrocarbon compositions in a sequence of humic coals, cannel coals and oil shales from the Pictou Coalfield, Nova Scotia
}

\author{
W. Püttmann \\ Lehrstuhl für Geologie, Geochemie und Lagerstätten des Erdöls und der Kohle, RWTH Aachen, Lochnerstr. \\ 4-20, 51 Aachen, FRG.
}

and

W. Kalkreuth

Institute of Sedimentary and Petroleum Geology, Geological Survey of Canada 3303-33rd Street N.W., Calgary, Alberta T2L 2A7, Canada

Date Received May 25, 1988

Date Accepted August 15, 1988

\begin{abstract}
Thirty oil shale, cannel coal and humic coal samples from the Pennsylvanian Stellarton Group, Nova Scotia, Canada have been investigated in this study by means of organic geochemical methods including gas chromatography (GC) and gas chromatography/mass spectrometry (GC/MS). Hydrocarbon compositions of the solvent extracts were found to vary significantly with lithology and facies.

Analysis of the saturated hydrocarbon fractions revealed that the relative amounts of long-chain alkanes $\left(>C_{20}\right)$ compared to those of short-chain alkanes $\left(<\mathrm{C}_{20}\right)$ are higher in the humic coal than in the cannel coal and oil shale samples. Moreover, the humic coal is characterized by the presence of homodrimane as the dominant bicyclic alkane. In the oil shale and cannel coal samples, on the other hand, $\mathrm{C}_{15}$-bicyclanes are present as major sesquiterpenoid hydrocarbons.

Compounds such as biphenyl, dibenzofuran, fluorene and their mono-methylated and di-methylated homologues were shown to occur almost exclusively in the aromatic hydrocarbon fractions of the humic coal samples. Presumably, these compounds are products of the degradation of lignin during diagenesis. The bitumen compositions of cannel coal and oil shale samples are quite similar.
\end{abstract}

Trente échantillons de schiste bitumineux, de charbon de spores et pollens, et de charbon humique provenant du Groupe de Stellarton (Pennsylvanien de la Nouvelle-Ecosse, Canada) ont été analysés dans cette étude à l'aide de méthodes de géochimie organique comprenant la chromatographie en phase gazeuse (GC) et le couplage chromatographie en phase gazeuse spectrométrie de masse (GC/MS). On constata que les compositions d'hydrocarbures des extraits en solvant varient fortement selon la lithologie et le faciès.

Une analyse des fractions à hydrocarbures saturés révéla que la proportion des alcanes à longue chaîne $\left(>\mathrm{C}_{20}\right)$ par rapport aux alcanes à chaîne courte $\left(<\mathrm{C}_{20}\right)$ est plus élevée dans le charbon humique que dans les échantillons de charbon de spores et pollens et de schiste bitumineux. De plus, le charbon humique est caractérisé par la présence d'homodrimane comme alcane bicyclique principal. Par contre, dans les échantillons de schiste bitumineux et de charbon de spores et pollens, onnote la présence de $\mathrm{C}_{15}$-bicyclanes comme hydrocarbures sesquiterpénoïdes majeurs.

Certains composés, tels le biphényle, le dibenzofurane, le fluorène et leurs homologues mono- et diméthylés, se retrouvent presqu'exclusivement dans les fractions à hydrocarbures aromatiques des échantillons de charbon humique. Ces composés seraient le produit de la dégradation de la lignine durant la diagenèse. Les compositions bituminiques des échantillons de charbon de spores et pollens et des schiste bitumineux se ressemblent beaucoup.

[Traduit par le joumal]

\section{INTRODUCTION}

During the last decade, several approaches were used to study the chemical characteristics of coals and coal macerals.
Concentrates of sporinite and vitrinite isolated from British Carboniferous coals were studied by pyrolysis/mass spectrometry (Py/MS) and pyrolysis/gas chromatography (Py/GC) (Larter and Douglas, 1978; Allan and Larter, 1983). Moreover, Curie

Geological Survey of Canada Contribution No. 36888.

ATLANTIC GEOLOGY

25, 93-103 (1989) 
Point - Py/GC and Curie Point - Py/GC/MS has been extensively applied to analyze maceral concentrates (Nip et al., 1988).

The analysis of solvent extracts of maceral concentrates revealed, that the hydrocarbon distribution is largely independent of the macerals within a single bituminous coal, which indicates intraseam homogenization of mobile organic compounds (Allan and Larter, 1983). In order to characterize the chemical nature of liptinite macerals, extracts of 'whole' coals each rich in one specific maceral were analyzed using GC/MS. It could be shown that distinct aromatic compounds are associated with specific macerals (Püttmann et al., 1986).

Moreover, the type of kerogen influences significantly the composition of coal pyrolysates. Larter and Douglas (1978) have shown, that pyrolysates of Type III kerogens are dominated by aromatic and phenolic compounds, whereas Type I kerogens provide aliphatic-rich pyrolysates. Further research is aimed at evaluating the influence during deposition of coals and shales of varying environmental conditions on the composition of the organic matter eventually generated. Variations in vitrinite reflectance values measured in iso-maturational samples have been interpreted as resulting from the paleoenvironmental conditions (Wenger and Baker, 1987). Some aspects of the variation in the extractable organic matter of coals and adjacent shales have previously been studied by Altebäumer (1983). In the present study, a set of 30 samples covering a $6 \mathrm{~m}$ oil shale, cannel coal and humic coal sequence of the McLeod horizon (Borehole P-29, Pictou Coalfield, Nova Scotia, Fig. 1) was studied by means of organic geochemical methods including gas chromatography (GC) and gas chromatography/mass spectrometry (GC/MS). Analyses were carried out on fractions of saturated and aromatic hydrocarbons.

\section{EXPERIMENTAL}

The sample material was collected from borehole P-29, Pictou Coalfield, Nova Scotia over a depth interval from 321.37$327.31 \mathrm{~m}$ (Figs. 1,6). The sample intervals (Fig. 6) were chosen according to macroscopic features such as differences in streak, texture, fracture style and toughness (Naylor et al., 1985). Solvent extraction of the finely ground $(<0.2 \mathrm{~mm})$ coal and shale samples as well as separation of the extracts by column chromatography and gas chromatographic analysis of the hydrocarbon fractions were carried out using procedures described previously (Püttmann and Villar, 1987). GC/MS analyses were performed on a Varian 3700 gas chromatograph coupled to a Finnigan MAT 8200 mass spectrometer (electron potential $70 \mathrm{eV}$ ) using a $25 \mathrm{~m}$ $x 0.25 \mathrm{~mm}$ fused silica column coated with SE 54. The temperature of the GC oven was programmed to increase from 80 to $300^{\circ} \mathrm{C}$ at a rate of $4^{\circ} \mathrm{C}$ per minute. Helium was used as the carrier gas. Mass spectra were recorded in the cyclic scan mode from 50 to 700 mass units over a total cycle time of 1.1 seconds. Data were processed with an INCOS data system. Compound identification was carried out by comparing mass spectra with standard spectra from the NBS library and spectral data published previously (Alexander et al., 1984, 1986; Püttmann et al., 1988).

Organic carbon contents $\left(\mathrm{C}_{\text {org }}\right)$ were determined using a LECO WR-12 carbon analyser. Carbonates were removed from the samples by prior treatment with concentrated hydrochloric acid. Vitrinite reflectance data were obtained using a Leitz MPV II microscope, applying standard procedures (Bustin et al., 1983).

\section{RESULTS}

\section{Petrographic Characteristics}

\section{Maturation}

Maturation levels of coals, cannel coals and oil shales were determined by vitrinite reflectance measurements (Table 1). The reflectance values range from 0.79 to $0.97 \%$ which places all samples at a maturation level generally considered to be favourable for the generation of hydrocarbons.

\section{Petrographic composition}

Petrographic composition was determined by maceral analyses. The coal samples are characterized by the predominance of macerals derived from woody precursors (vitrinite and inertinite) whereas in the oil shale and cannel coals the main component is the liptinite maceral alginite. For further details on petrographic variations in this sequence the reader is referred to Paul et al. (1989).

\section{Saturated Hydrocarbons}

The gas chromatograms of the saturated hydrocarbon fractions obtained from extracts of samples from the McLeod horizon revealed similar compound pattems in many of the GC traces. Consequently, only three selected gas chromatgrams of saturated hydrocarbon fractions representing an oil shale (A 36), a cannel coal (A 32) and a humic coal (A 21) are shown in Figure 2. The distribution of the $n$-alkanes is virtually identical in the oil shale and cannel coal samples, maximizing in the $C_{15}$ carbon atom range. The relative intensity of the n-alkanes continuously decreases towards longer chain-lengths without showing any odd-over-even predominance. In contrast, the $n$-alkane distribution of the humic coal (A 21) is characterized by relatively high intensities of long-chain alkanes and by a slight odd-over-even predominance (except for $\mathrm{C}_{24}$ ). Both phenomena indicate greater terrestrial plant input in the humic coal compared to that of the cannel coal and oil shale samples.

An additional characteristic which distinguishes oil shale and cannel coal from humic coal is the occurrence of $\mathrm{C}_{15}$ bicyclanes previously identified in crude oils (Alexander $e t$ al., 1984) in the former (peaks 1 and 2, Fig. 2). These compounds are believed to be derived from rearrangement processes of drimanerelated precursors (Kagramanova et al., 1976), which in turn are thought to originate mainly from the fragmentation of pentacyclic triterpenoids (Alexander et al., 1984), probably via the formation of monoaromatic 8,14-secohopanoids (Hussler et al., 1984). Both $C_{15}$-bicyclanes (peaks 1,2 ) are absent from the humic coal extracts. Instead, the humic coals contain homodrimane as the major bicyclic alkane. The compound is present as 


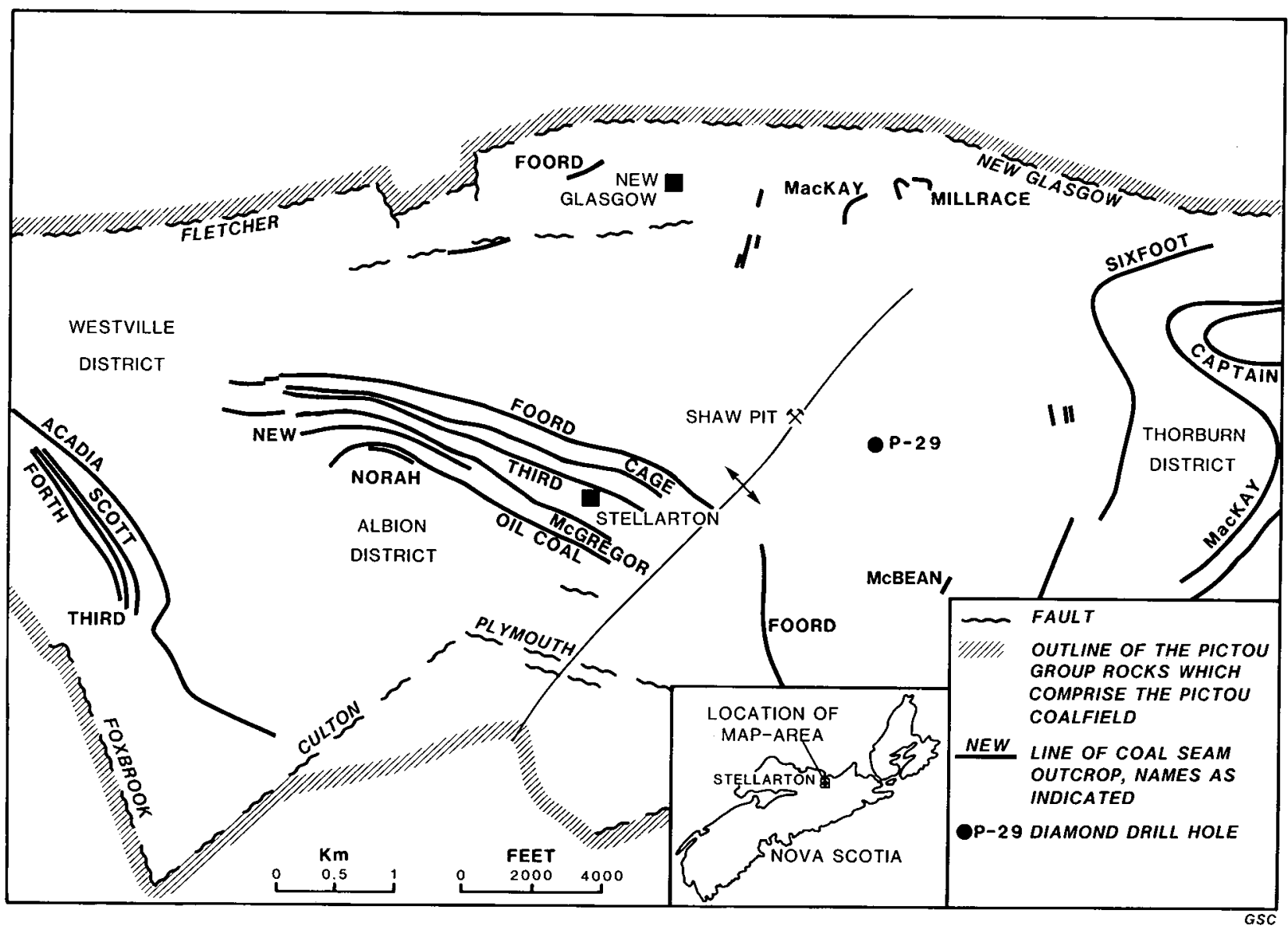

Fig. 1. Study area and location of borehole P-29.

the $8 B(H)$-epimer which is suggested to be generated from the $8 \alpha(\mathrm{H})$-homodrimane during maturation (Noble et al., 1987). Investigations carried out on a set of coals of the Ruhr- and Saar districts (F.R. Germany) also revealed the presence of homodrimane (associated with drimane) as the dominant bicyclic hydrocarbons (Püttmann, unpublished results) which indicates an association of both compounds with higher plant material.

Mass chromatograms of $\mathrm{m} / \mathrm{z}=123$ were recorded in order to substantiate the differences in distributions of bicyclic alkanes (Fig. 3). The complex distribution pattern of $\mathrm{C}_{15}$-bicyclanes and $\mathrm{C}_{16}$-bicyclanes in the cannel coal (A 32, upper trace) is almost indistinguishable from the one obtained from the oil shale (A 36, not shown here), but differs distinctly from the humic coal extract (A 21, lower trace). The high concentration of these compounds in A 32 (cannel coal) may either originate from the particular type of plant input or from drimane and homodrimane through rearrangement reactions that have resulted from the specific depositional environment.

A further significant difference between the humic coal and cannel coal/oil shale facies is provided from analysis of isoprenoid hydrocarbons (Fig. 2). Compounds such as farnesane (peak 4), 2,6,10-trimethyltridecane (peak 5), norpristane (peak 6), pristane (peak 7) and phytane (peak 8) are enriched relative to nalkanes in the humic coal horizon (A 21) but are of minor importance in the cannel coal (A 32) and oil shale (A 36). Results obtained from hydrocarbon group separation (Table 1) show that in the cannel coal and oil shale extracts the percentage of alkanes is higher than in the humic coal samples. Thus, their relatively low content of isoprenoid hydrocarbons may be due to the increased intensity of $n$-alkanes in the cannel coal/oil shale samples.

\section{AROMATIC HYDROCARBONS}

Comparison of gas chromatograms obtained from the aromatic hydrocarbon fractions of samples A 36, A 32 and A 21 (Fig. 4) reveals a trend much like the one observed for the saturated hydrocarbons. Again, a significant similarity in the compound distribution in the oil shale (A 36) and cannel coal (A 32) extract is observed. Both aromatic fractions are dominated by naphthalenes (peaks 9,10,11, 12) and phenanthrenes (peaks 14, 15, 16). Additional aromatic compounds are present in minor amounts only. In contrast, the aromatic hydrocarbon fraction of the humic coal extract (A 21) contains further peaks in the GC trace. GC/ MS analysis has been undertaken for the identification of these compounds. In Figure 5, two sections of the reconstructed ion currents (RIC) of a humic coal samples (A 24) and an oil shale/ cannel coal sample (A 35) are shown. In the upper trace (A 35) the di-, tri-, and tetramethylnaphthalenes (peaks $11,12,13$ ) as well as phenanthrene (14) are the dominant compounds. In the lower trace (A 24) an additional set of aromatic constituents is detectable. This set can be divided into three sub-groups. One 


\begin{tabular}{|c|c|c|c|c|c|c|c|c|c|c|c|c|}
\hline Lithology & $\begin{array}{l}\text { samplel } \\
\text { no. }\end{array}$ & $\begin{array}{l}\mathrm{C}_{\text {org }} \\
(\%)\end{array}$ & $\begin{array}{l}\text { mg ext/ } \\
\text { g C }_{\text {org }}\end{array}$ & $\begin{array}{l}\text { sat } \\
(\%)\end{array}$ & $\begin{array}{l}\text { aro } \\
(\%)\end{array}$ & $\begin{array}{l}\text { het } \\
(\%)\end{array}$ & $\begin{array}{l}\text { prid } \\
\text { phy }\end{array}$ & $\begin{array}{l}\mathrm{pr} \cdot \mathrm{i} / \\
\mathrm{n}-\mathrm{C}_{17}\end{array}$ & MPR & Mèan & $\begin{array}{l}\text { Rrandom }(\%) \\
\mathrm{S}\end{array}$ &. $\mathrm{V}$ \\
\hline Oil Shale & A 36 & 8.49 & 54.1 & 26.6 & 33.0 & 17.3 & 1.89 & 0.20 & 0.71 & 0.82 & 0.07 & 8 \\
\hline Oil Shale & A 35 & 17.18 & 45.0 & 27.6 & 36.0 & 14.5 & 2.26 & 0.21 & 0.72 & $0.80^{2}$ & 0.04 & 25 \\
\hline Cannel Coal & A 32 & 17.60 & 70.3 & 22.0 & 38.6 & 15.8 & 2.85 & 0.16 & 0.71 & $0.89^{2}$ & 0.04 & 25 \\
\hline Siderite Band & A 31 & 10.82 & 65.3 & 24.6 & 30.1 & 14.4 & 1.60 & 0.20 & 0.64 & 0.79 & 0.09 & 13 \\
\hline Cannel Coal & A 30 & 21.70 & 75.6 & 22.4 & 38.1 & 14.8 & 1.95 & 0.17 & 0.68 & $0.90^{2}$ & 0.05 & 50 \\
\hline Coaly Shale & A 28 & 15.80 & 65.5 & 35.4 & 32.5 & 9.5 & 2.89 & 0.25 & 0.68 & $0.90^{2}$ & 0.05 & 50 \\
\hline Coal & A 27 & 58.60 & 16.6 & 27.9 & 40.6 & 9.0 & 3.96 & 0.16 & 0.85 & $0.85^{2}$ & 0.03 & 50 \\
\hline Coal & A 26 & 70.28 & 12.5 & 19.0 & 34.1 & 10.6 & 6.11 & 0.32 & 1.07 & $0.89^{2}$ & 0.04 & 50 \\
\hline Coal & A 25 & 53.30 & 21.2 & 22.5 & 42.0 & 16.2 & 9.59 & 0.71 & 1.15 & 0.972 & 0.04 & 50 \\
\hline Coal & A 24 & 69.30 & 14.4 & 19.8 & 38.8 & 17.1 & 5.59 & 0.26 & 1.33 & $0.94^{2}$ & 0.04 & 50 \\
\hline Coall & A 23 & 73.80 & 12.6 & 19.0 & 43.2 & 17.8 & 7.41 & 0.32 & 1.32 & $0.96^{2}$ & 0.04 & 50 \\
\hline Coal & А 22 & 69.10 & 14.4 & 17.3 & 43.2 & 17.0 & 6.12 & 0.40 & 1.35 & 0.952 & 0.03 & 50 \\
\hline Coall & A 21 & 37.40 & 18.8 & 13.8 & 47.1 & 25.3 & 6.49 & 0.79 & 1.35 & $0.84^{2}$ & 0.04 & 50 \\
\hline Coall & A 20 & 55.70 & 14.0 & 13.0 & 46.8 & 13.3 & 7.46 & 0.72 & 1.32 & $0.90^{2}$ & 0.04 & 50 \\
\hline Coill & A 19 & 29.20 & 13.0 & 14.2 & 38.3 & 15.9 & 6.51 & 0.83 & 1.42 & $0.91^{2}$ & 0.04 & 50 \\
\hline Coall & A 18 & 39.30 & 12.1 & 17.3 & 47.5 & 18.7 & 6.40 & 0.69 & 1.45 & $0.84^{2}$ & 0.04 & 50 \\
\hline Coill & A 17 & 27.50 & 15.8 & 12.7 & 47.7 & 23.3 & 5.64 & 0.47 & 1.40 & $0.84^{2}$ & 0.05 & 50 \\
\hline Coul & A 16 & 45.50 & 12.5 & 12.9 & 51.9 & 35.9 & 6.13 & 0.70 & 1.38 & $0.79^{2}$ & 0.04 & 50 \\
\hline Coill & A 15 & 35.80 & 14.0 & 11.3 & 43.7 & 14.7 & 7.89 & 0.66 & 1.42 & $0.80^{2}$ & 0.04 & 50 \\
\hline Coaly Shale & A 14 & 23.40 & 16.2 & 16.3 & 46.9 & 24.5 & 7.18 & 0.59 & 1.44 & $0.85^{2}$ & 0.05 & 50 \\
\hline Coatl & A 13 & 39.60 & 16.5 & 16.6 & 44.4 & 25.5 & 7.22 & 0.74 & 1.94 & $0.84^{2}$ & 0.04 & 50 \\
\hline Coaly Shale & A 12 & 12.00 & 35.8 & 23.5 & 41.3 & 22.1 & 5.60 & 0.77 & 1.28 & $0.83^{2}$ & 0.05 & 50 \\
\hline Oil Shale & A 10 & 7.08 & 47.5 & 15.1 & 33.0 & 20.1 & 9.82 & 0.62 & 0.98 & $0.85^{2}$ & 0.04 & 25 \\
\hline (Oil Shale & A 9 & 6.92 & 59.0 & 16.3 & 39.0 & 19.5 & 4.77 & 0.70 & 1.01 & 0.912 & 0.03 & 25 \\
\hline OilShale & A 8 & 6.26 & 69.7 & 19.1 & 32.4 & 17.2 & 4.46 & 0.75 & 1.02 & 0.85 & 0.07 & 50 \\
\hline Oil Shale & A 7 & 4.64 & 67.4 & 24.1 & 27.1 & 14.7 & 3.42 & 0.43 & 0.98 & 0.82 & 0.07 & 50 \\
\hline Oil Shale & A 6 & 3.24 & 51.1 & 21.0 & 26.7 & 18.2 & 4.26 & 0.50 & 0.88 & 0.81 & 0.06 & 49 \\
\hline Ciannel Coal & A 5 & 6.40 & 57.0 & 21.4 & 28.4 & 17.4 & 3.23 & 0.48 & 0.82 & 0.91 & 0.06 & 50 \\
\hline Oil Shale & A 4 & 2.70 & 52.2 & 21.6 & 23.6 & 25.1 & 3.07 & 0.32 & 0.98 & 0.85 & 0.07 & 50 \\
\hline Oil Shale & A 3 & 4.70 & 46.0 & 11.3 & 24.6 & 12.0 & 4.30 & 0.60 & 0.94 & $0.91^{2}$ & 0.04 & 25 \\
\hline
\end{tabular}

Abbreviations: $\mathrm{C}_{\text {org }}=$ organic carbon content, ext $=$ extract

sat $=$ saturated hydrocarbons, aro $=$ aromatic hydrocarbons,

het $=$ heterocomponents, $\mathrm{pr} \cdot \mathrm{i}$ phy $=$ pristane/phytane, $\mathrm{n}-\mathrm{C}_{17}=$ heptadecane

$. \mathrm{IPR}=$ methylphenanthrene ratio according to Radke et al., (1982)

Rrandom = Mean random vitrinite reflectance, $S=$ Standard deviation, $N=$ Number of measurements

1 for sample depth and thickness of sample interval see Fig. 6

- reflectance data from Paul (1988) 

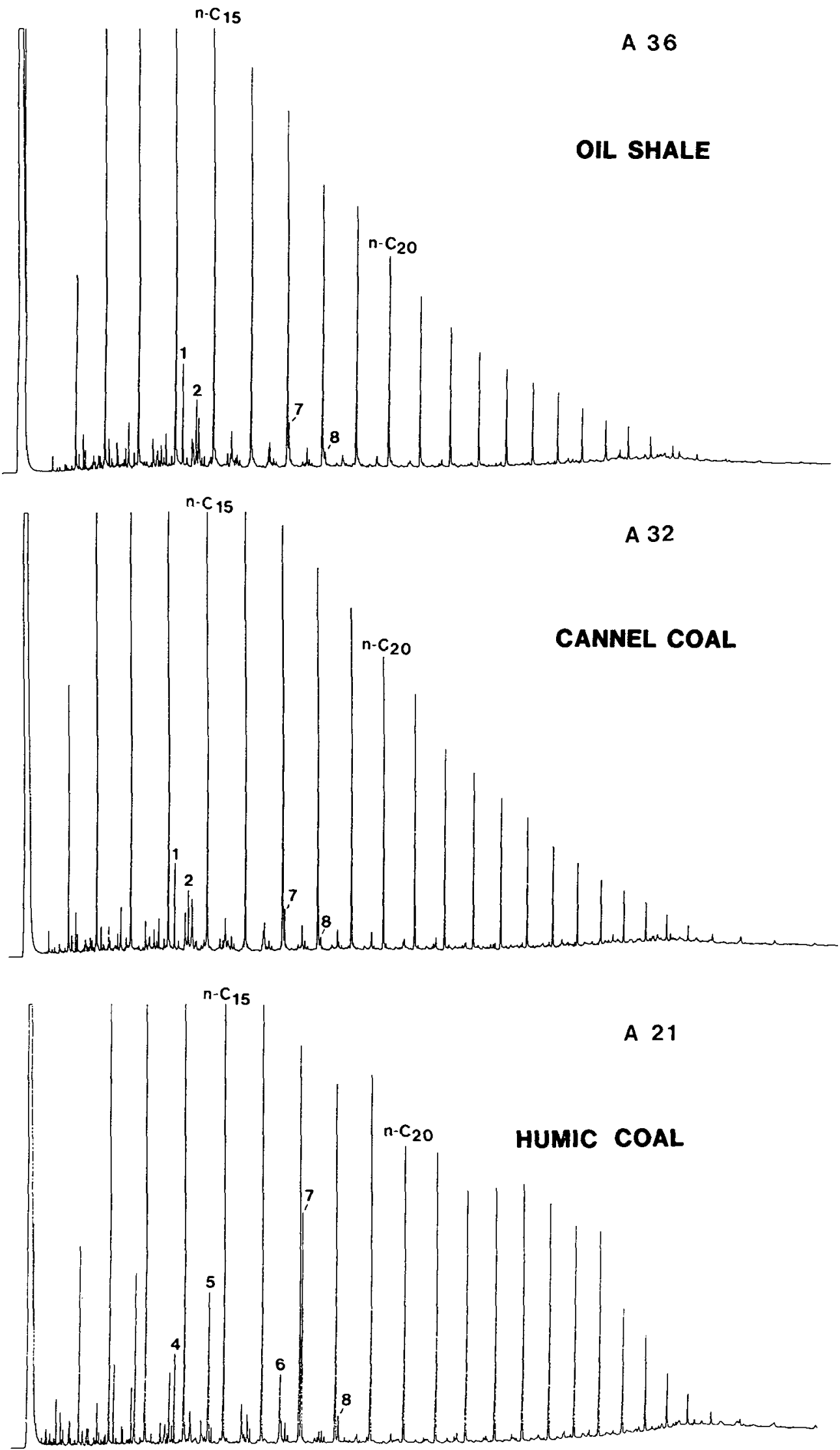

Fig. 2. Gas chromatograms of saturated hydrocarbon fractions obtained from samples A 36 (oil shale), A 32 (cannel coal) and A 21 (humic coal). For peak identification see Table 2. 
Table 2. Compounds identified in the saturated and aromatic hydrocarbon fractions.

\begin{tabular}{|c|c|}
\hline Number & Name of Compound \\
\hline 1 & $\mathrm{C}_{15}$-bicyclic alkane \\
\hline 2 & $\mathrm{C}_{15}$-bicyclic alkane \\
\hline 3 & homodrimane \\
\hline 4 & farnesane \\
\hline 5 & $2,6,10$-trimethyltridecane \\
\hline 6 & norpristane \\
\hline 7 & pristane \\
\hline 8 & phytane \\
\hline 9 & naphthalene \\
\hline 10 & $2-, 1-$ methylnaphthalene \\
\hline 11 & $\mathrm{C}_{2}$-naphthalenes \\
\hline 12 & $\mathrm{C}_{3}$-naphthalenes \\
\hline 13 & $\mathrm{C}_{4}$-naphthalenes \\
\hline 14 & phenanthrene \\
\hline 15 & methylphenanthrenes \\
\hline 16 & $\mathrm{C}_{2}$-phenanthrenes \\
\hline 17 & biphenyl \\
\hline 18 & 3-methylbiphenyl \\
\hline 19 & 4-methylbiphenyl \\
\hline 20 & dibenzofuran \\
\hline 21 & fluorene \\
\hline 22 & $\mathrm{C}_{2}$-biphenyls \\
\hline 23 & methyldibenzofurans \\
\hline 24 & methylfluorenes \\
\hline 25 & $\mathrm{C}_{2}$-dibenzofurans \\
\hline
\end{tabular}

represents biphenyl (peak 17), 3-methylbiphenyl (peak 18), 4methylbiphenyl (peak 19) and $C_{2}$-biphenyls (peaks 22). This set of compounds has previously been identified in the aromatic fraction of Homestead, Kentucky coal (White and Lee, 1980), in coal tar (Mostecky et al., 1970) and in ancient sediments and crude oils (Alexander et al., 1986; Cumbers et al., 1987). Given the widespread occurrence of these compounds, a single source cannot be postulated. However, the analysis of thermally desorbed hydrocarbons in coals revealed that biphenyl and methylbiphenyls substantially contribute to the bitumen composition of higher rank (medium volatile bituminous) humic coals (Schaefer and Püttmann, 1987; Püttmann et al., 1988). Thus, a predominantly higher plant source for these aromatic compounds can be assumed. This is in accordance with the observed high intensities of biphenyl and its alkylated derivatives in the humic coal sequence of the McLeod horizon (Fig. 5).

This view is also confirmed by the co-occurrence of dibenzofuran (peak 20) and a set of methylated derivatives (peaks 23, 25) exclusively in the humic coal samples (Fig. 5). Again, these compounds have previously been identified in coal extracts (White and Lee, 1980; Radke et al., 1982). In addition, dibenzofuran was shown to be generated from a bituminous coal, when treated with aqueous sodium dichromate (Hayatsu et al., 1978). This indicates that abundant potential precursors of this compound are present in coal and are liberated under oxidizing conditions. The third set of compounds identified in the humic coal extract (A 24, Fig. 5), comprising fluorene (peak 21) and methylfluorenes (peaks 24), was also reported to be primarily present in coal extracts (White and Lee, 1980; Radke et al., 1982). This is a further indication that all these compounds are major
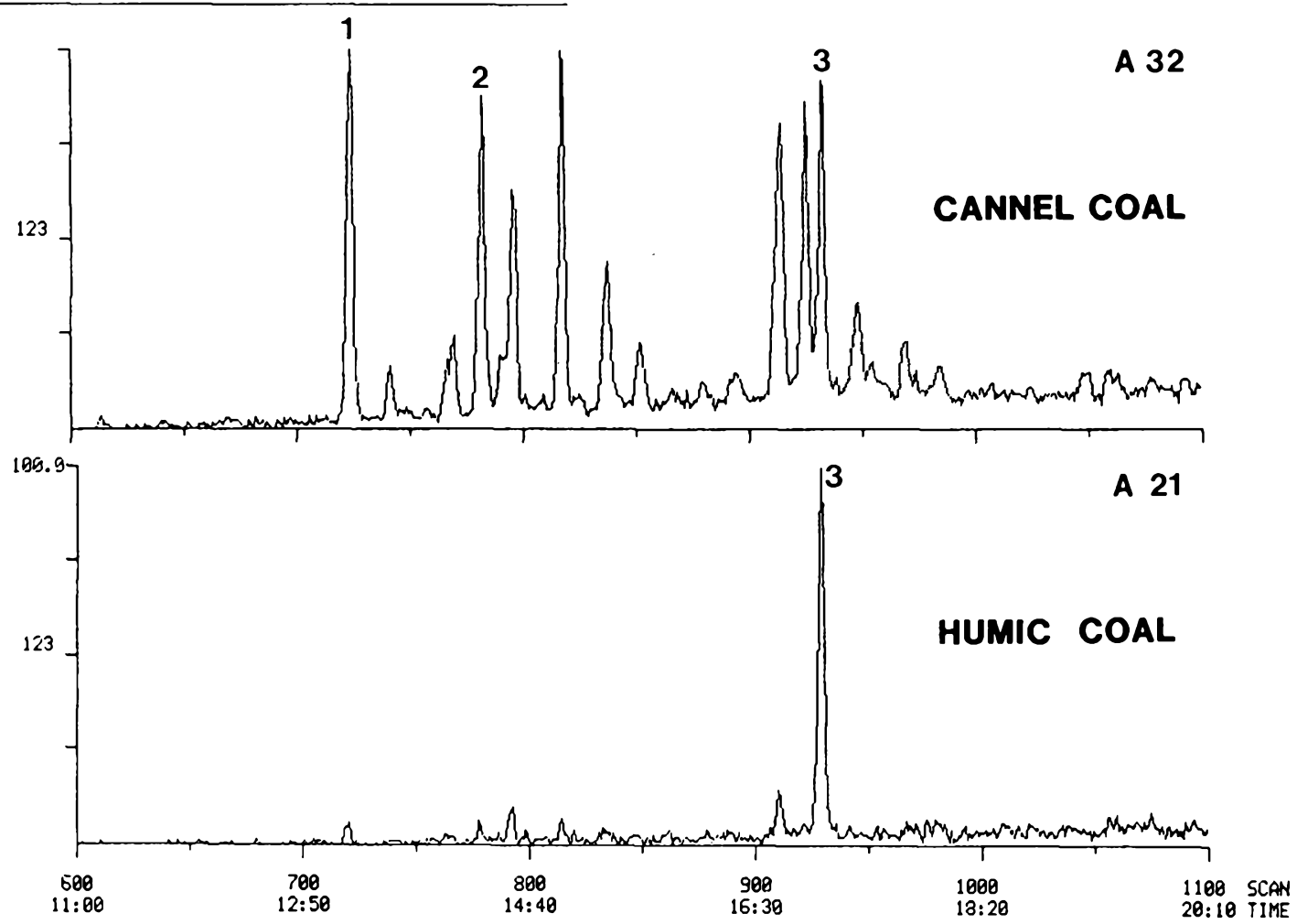

Fig. 3. GC/MS analysis of saturated hydrocarbon fractions: mass chromatograms of $\mathrm{m} / \mathrm{z}=123$ in the scan range from 600 to 1100 for the recognition of bicyclic alkanes in samples A 32 (cannel coal) and A 21 (humic coal). Assignment of numbered peaks is given in Table 2. 

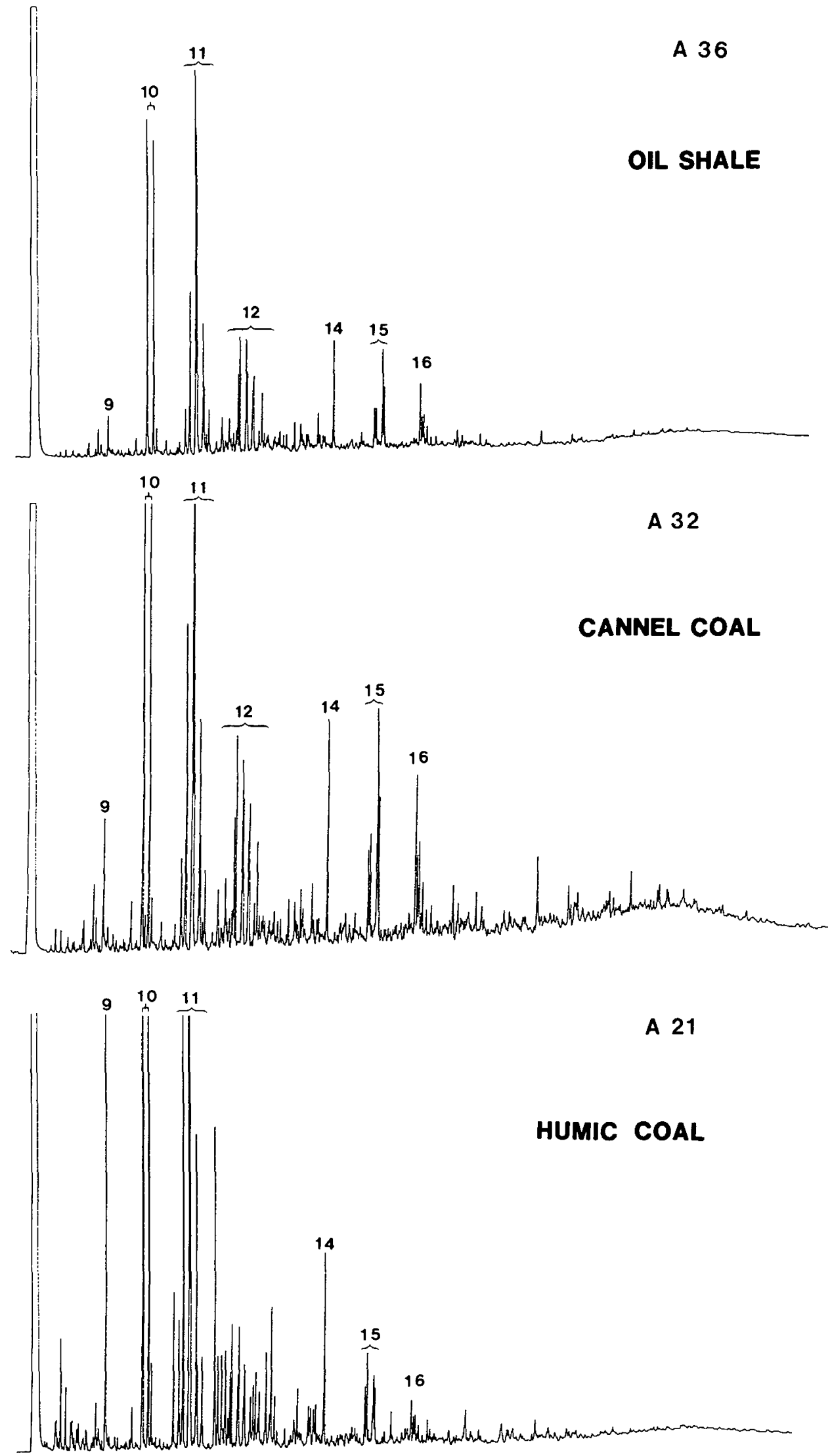

Fig. 4. Gas chromatograms of aromatic hydrocarbon fractions obtained from samples A 36 (oil shale), A 32 (cannel coal) and A 21 (humic coal). Assignment of numbered peaks is given in Table 2. 

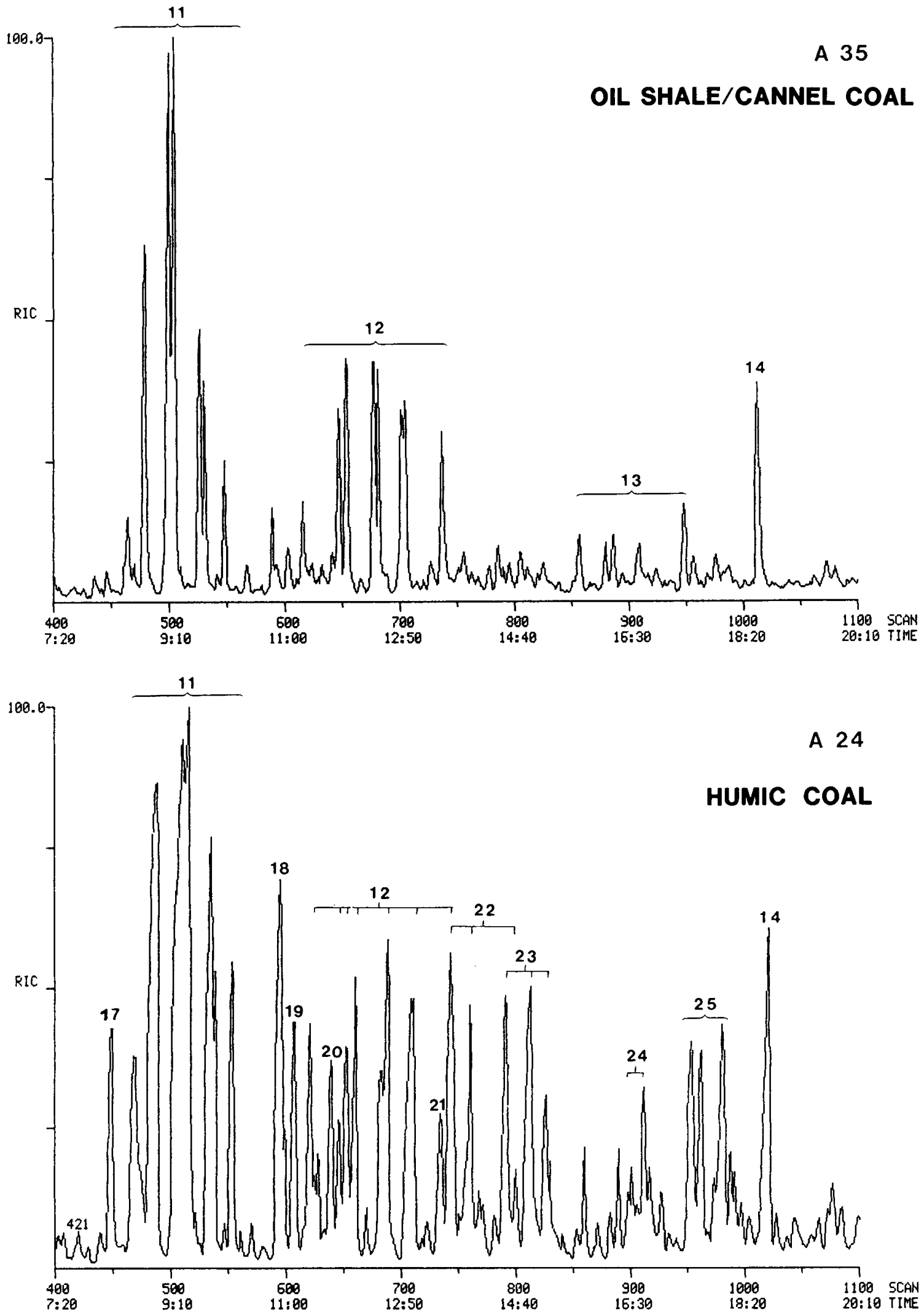

Fig. 5. GC/MS analysis of aromatic hydrocarbon fractions in samples A 35 (oil shale/cannel coal) and A 24 (humic coal): reconstructed ion currents (RIC) in the scan range from 400 to 1100 . Assignment of numbered peaks is given in Table 2. 
coalification products generated in humic coals. In the structural scheme of carboniferous lignin (Freudenberg, 1964), biphenyls as well as bibenzofurans and fluorenes are represented by possible precursor moieties. Thus, lignin may be regarded as the source for this particular type of aromatic constituents. The low intensity of these compounds in the cannel coal and oil shale samples indicates a minor contribution of such precursors in this type of facies. Hydrocarbon group separation results confirm this (Table 1). The humic coal horizon is characterized by relatively low amounts of saturated hydrocarbons $(<20 \%)$ and high amounts of aromatic hydrocarbons ( $>40 \%)$ in the extracts. In the cannel coal and oil shale samples a reverse tendency is observed, indicating a higher degree of aromaticity in the humic coal horizon.

\section{BIOMARKER RATIOS}

When comparing the cannel coal/oil shale and the humic coal horizon a substantial facies change is evident from biomarker ratios. As shown in Figure 6, the pristane/phytane ratio is significantly higher in the humic coal samples compared to the adjacent cannel coals and oil shales. A similar trend can be observed in the pristane/ $\mathrm{n}-\mathrm{C}_{17}$ ratio. Since there is no evidence of migration effects and of significant differences in the maturation of the samples investigated, both observations point to a source for pristane that is preferentially associated with the humic coal horizon. Additionally, the methylphenanthrene ratio (MPR) introduced by Radke et al. (1982) is strongly affected by facies changes. The significant increase of this ratio (Fig. 6) in the
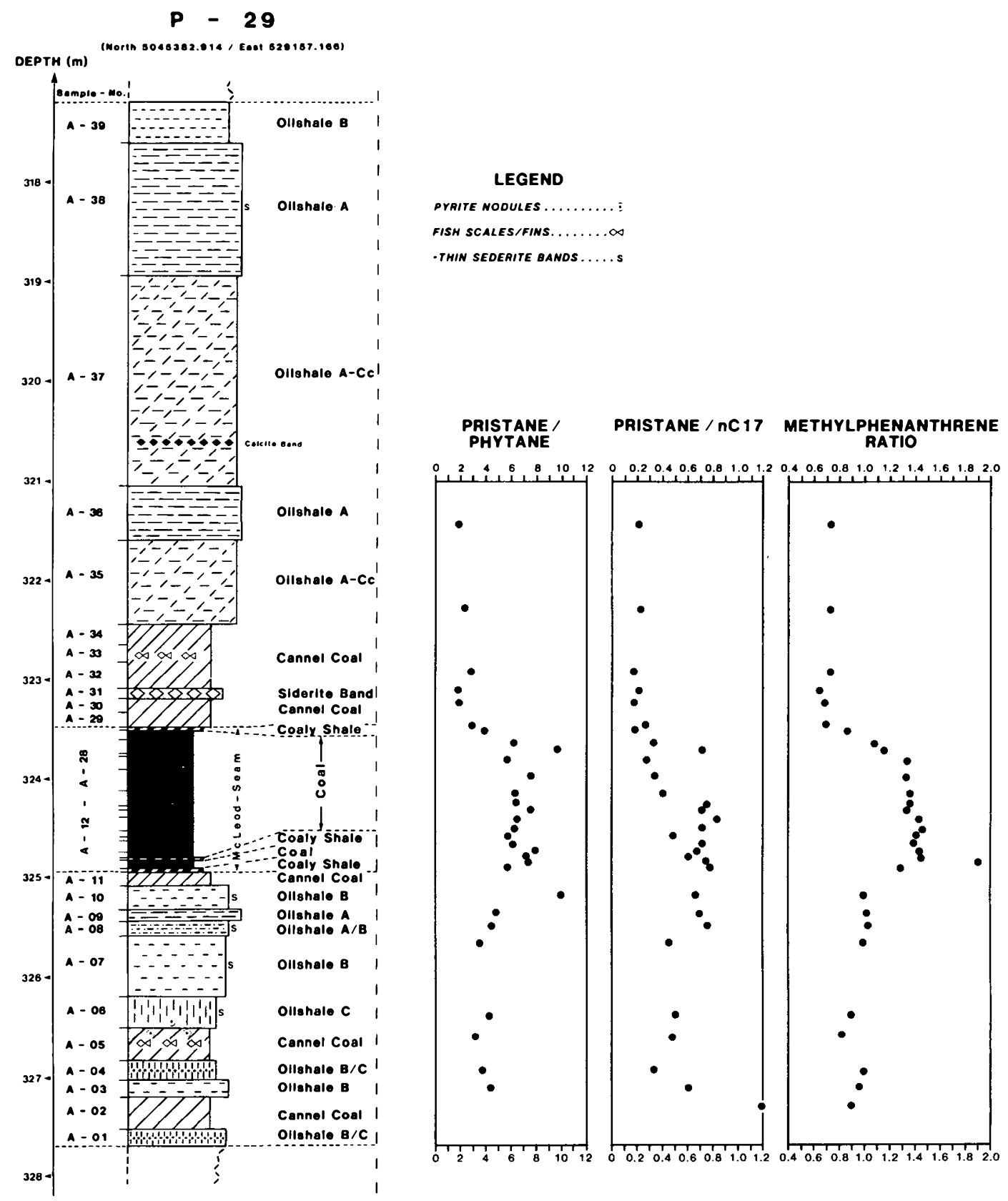

Fig. 6. Plot of biomarker ratios (pristane/phytane, pristane/n- $\mathrm{C}_{17}$ and methylphenanthrene ratio) determined in 30 samples relative to the geological profile. 
humic coal samples results from the predominance of 2-methylphenanthrene within the pattern of methylphenanthrenes. The cannel coal/oil shale samples, however, are characterized by a predominance of 9-methylphenanthrene as shown by GC/MS analysis of samples A 21 and A 35 (Fig. 7). This is further evidence of a major change in the organic matter input. Thus, the MPR has a limited applicability for maturity estimation in sequences of varying lithologies but may be good for organic facies recognition.
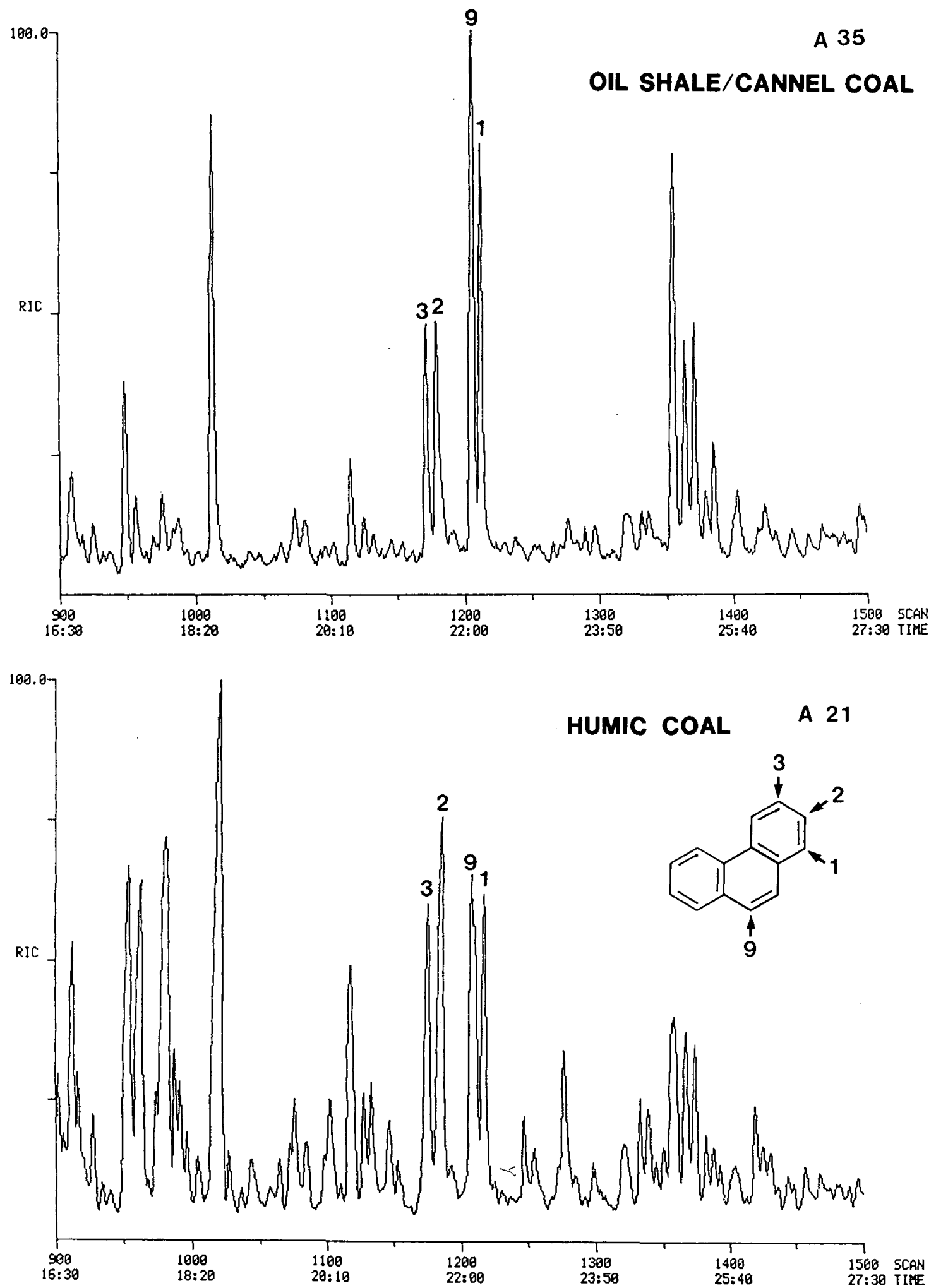

Fig. 7. GC/MS analysis of aromatic hydrocarbon fractions: reconstructed ion currents (RIC) in the scan range from 900 to 1500 for the recognition of methylphenanthrenes in samples A 35 (oil shale/cannel coal) and A 21 (humic coal). 


\section{CONCLUSIONS}

In conclusion, the results presented herein indicate that chemical examination of bituminous constituents of the lithology termed "cannel coals" leads us to consider them as organic-rich oil shales rather than coals. Major changes in extract composition are detected only at the facies border of the cannel to humic coals. Microscopically, however a substantial change in vitrinite reflectance values was not observed at this border (Table 1 ). Thus, the significant variations in vitrinite reflectance values associated with organic facies changes, detected previously in other organic-rich successions (Hutton and Cook, 1980; Kalkreuth, 1982; Kalkreuth and Macauley, 1987; Wenger and Baker, 1987) are not corroborated in the present study. Further research will be required to elucidate this problem.

ALEXANDER, R., KAGI, R.I., NOBLE, R., and VOLKMAN, J.K. 1984. Identification of some bicyclic alkanes in petroleum. Organic Geochemistry, 6, pp. 63-70.

ALEXANDER, R., CUMBERS, K.M., and KAGI, R.I. 1986. Alkylbiphenyls in ancient sediments and petroleums. In Advances in Organic Geochemistry 1985. Edited by D. Leythaeuser and J. Rullkötter. Organic Geochemistry, 10, Pergamon Press, Oxford, pp. 841-845.

ALLAN, J. and LARTER, S.R. 1983. Aromatic structures in coal maceral extracts and kerogens. In Advances in Organic Geochemistry 1981. Edited by Bjorøy et al. John Wiley and Sons, Chichester, pp. 534-545.

ALTEBÄUMER, A. 1983. Geochemische Untersuchungen zur Klärung des Einflusses der Fazies sowie der primären Migration auf Menge und Zusammensetzung des organischen Materials im Flöz Katharina (Westfal A) und in den hangenden Schiefertonen (Westfal B) im Ruhrkarbon. Ph.D. thesis, University of Aachen (Rheinisch Westfälische Technische Hochschule), Department of Geology, $306 \mathrm{p}$.

BUSTIN, R.M., CAMERON, R.A.,GRIEVE,D.A., and KALKREUTH, W.D. 1983. Coal petrology - its principles, methods and applications. Geological Association of Canada, Short Course Notes, 3, $273 \mathrm{p}$.

CUMBERS, K.M., ALEXANDER, R., and KAGI, R.I. 1987. Methylbiphenyl, ethylbiphenyl and dimethylbiphenyl isomer distributions in some sediments and crude oils. Geochimica et Cosmochimica Acta, 51, pp. 3105-3112.

FREUDENBERG, K. 1964. Entwurf eines Konstitutionsschemas für das Lignin der Fichte. Holzforschung, 18, pp. 3-9.

HAYATSU, R., WINANS, R.E., SCOTT, R.G., MOORE, L.P., and STUDIER, M.H. 1978. Trapped organic compounds and aromatic units in coal. Fuel, 57, pp. 541-548.

HUSSLER, G., CONNAN, J., and ALBRECHT, P. 1984. Novel families of tetra- and hexacyclic aromatic hopanoids predominant in carbonate rocks and crude oils. Organic Geochemistry, 6, pp. 3949.

HUTTON, A. and COOK, A. 1980. Influence of alginite in the reflectance of vitrinite from Joadja, N.S.W., and some other coals and oil shales containing alginite. Fuel, 59, pp. 711-716.

KAgRAMANOVA, G.R., PUSTIL'NIKOVA, S.D., PEHK, D., DENISOV, Y.V., and PETROV, A.A. 1976. Sesquiterpane hydrocarbons of petroleum. Neftekhimiya, 16, pp. 18-22 (in Russian).

KALKREUTH, W.D. 1982. Rank and petrographic composition of selected Jurassic - Lower Cretaceous coals of British Columbia.
Bulletin of Canadian Petroleum Geology, 30, pp. 112-139.

KALKREUTH,W. and MACAULEY,G. 1987. Organic Petrology and Geochemical (Rock-Eval) Studies on Oil Shales and Coals from the Pictou and Antigonish Areas, Nova Scotia. Bulletin of Canadian Petroleum Geology, 35, pp. 263-295.

LARTER, S.R. and DOUGLAS, A.G. 1978. Low molecular weight aromatic hydrocarbons in coal maceral pyrolysates as indicators of diagenesis and organic matter type. In Environmental Biogeochemistry and Geomicrobiology. Edited by W.A. Krumbein. Ann Arbor, Michigan, pp. 373-386.

MOSTECKY, J., POPL, M., and KRIZ, J. 1970. Determination of $C_{12}$ alkylnaphthalenes and methylbiphenyls in aromatic fractions by capillary gas chromatography. Analytical Chemistry, 42, pp. 1132-1135.

NAYLOR, R., PRIME, G., and SMITH, W. 1985. Preliminary report on the oil shales of Stellarton Basin, Pictou County, Nova Scotia. In Program and Summaries, 9th Annual Open House and Review of Activities, Nova Scotia Department of Mines and Energy, Information Series No. 9, pp. 11-14.

NIP, M., DE LEEUW, J.W., and SCHENCK, P.A. 1988. Characterization of eight maceral concentrates by means of Curie Point pyrolysis - gas chromatography and Curie Point pyrolysis - gas chromatography - mass spectrometry. Geochimica et Cosmochimica Acta, 52, pp. 637-648.

NOBLE, R.A., ALEXANDER, R., and KAGI, R.I. 1987. Configurational isomerization in sedimentary bicyclic alkanes. Organic Geochemistry, 11, pp. 151-156.

PAUL, J. 1988. Kohlenpetrographische und geochemische Untersuchungen an Kohlen und Olschiefern des McLeod - Horizontes, Pictou Coalfield, Nova Scotia, Canada. Unpublished M.Sc. thesis, University of Cologne, Department of Geology, Cologne, Germany, 75 p.

PAUL, J., KALKREUTH, W., NAYLOR, R., and SMITH, W. 1989. Petrology, Rock Eval and facies analyses of the McLeod coal seam and associated beds, Pictou Coalfield, Nova Scotia. Atlantic Geology, 25, pp. 81-92

PUTTMANN, W. and VILLAR, H. 1987. Occurrence and geochemical significance of 1,2,5,6-tetramethylnaphthalene. Gcochimica et Cosmochimica Acta, 51, pp. 3023-3029.

PUTTMANN, W., WOLF, M., and WOLFF-FISCHER, E. 1986. Chemical characteristics of liptinite macerals in humic and sapropelic coals. In Advances in Organic Geochemistry 1985. Edited by D. Leythaeuser and J. Rullkötter. Organic Geochemistry, 10, Pergamon Press, Oxford, pp. 625-632.

PUTTMANN, W., ECKARDT, C.B., and SCHAEFER, R.G. 1988. Analysis of hydrocarbons in coal and rock samples by on-line combination of thermodesorption, gas chromatography and mass spectrometry. Chromatographia, 25, pp. 279-288.

RADKE, M., WILLSCH, H., LEYTHAEUSER, D., and TEICHMULLER, M. 1982. Aromatic components of coal: relation of distribution pattern to rank. Geochimica et Cosmochimica Acta, 46, pp. 1831-1848.

SCHAEFER, R.G. and PUTTMANN, W. 1987. Analysis of hydrocarbons in coal by means of thermodesorption - gas chromatography. Journal of Chromatography, 395, pp. 203-215.

WENGER, L.M. and BAKER, D.R. 1987. Variations in vitrinite reflectance with organic facies - Examples from Pennsylvanian cyclothems of the Midcontinent, U.S.A. Organic Geochemistry, 11 . pp. 411-416.

WHITE, C.M. and LEE, M.L. 1980. Identification and geochemical significance of some aromatic components of coal. Geochimica et Cosmochimica Acta, 44, pp. 1825-1832. 